\title{
Effect of increasing conjugated linoleic acid content on carcass characteristics of sheep*
}

\author{
Z.C.T.R. Daniel ${ }^{1}$, R.J. Wynn, C.L. Flux, A.M. Salter and P.J. Buttery \\ Division of Nutritional Biochemistry, School of Biosciences, \\ University of Nottingham, Sutton Bonington Campus \\ Loughborough, Leicestershire, LE12 5RD, UK
}

\begin{abstract}
Fat-reduction effects of conjugated linoleic acid (CLA) have been documented in rodents and pigs. Growing lambs were fed three levels of CLA or Megalac (MEG) which was fed to control for energy content. In adipose tissue, the proportions of both CLA isomers increased with CLA supplementation fed but not with Megalac inclusion. A similar dose accumulation with increasing CLA was seen for the trans-10, cis-12 isomer in samples of $L$. dorsi muscle. However, although the tissues had been enriched with CLA, there was no evidence of a fat reduction in these sheep.
\end{abstract}

KEY WORDS: conjugated linoleic acid, sheep, carcass

\section{INTRODUCTION}

Altering the fatty acid composition and fat:lean ratio of sheep tissues may be beneficial in terms of human health. Recent research has focused on a component of ruminant fat, conjugated linoleic acid (CLA), which has been implicated with numerous health promoting properties (Belury, 1995). A fat-reduction effect of CLA has been well documented in mice (Park et al., 1997; West et al., 1998), rats (Sisk et al., 2001) and pigs (Dugan et al., 1997; Ostrowska et al., 1999, 2003). More specifically Park et al. (1999) provided evidence that the influence of CLA on carcass composition is attributed to the trans-10, cis-12 isomer, which has also been linked to a reduction in milk fat content in dairy cows (Baumgard et al., 2001). However, there is little evidence to suggest dietary supplementation

\footnotetext{
R.J. Wynn was funded by a BBSRC CASE studentship with Pfizer and the authors wish to acknowledge J. Craigon (University of Nottingham) for statistical advice

${ }^{1}$ Corresponding author: e-mail: zoe.daniel@nottingham.ac.uk
} 
with CLA effect tissue composition in growing ruminants. Consequently, we hypothesized that feeding growing lambs a rumen-protected CLA supplement would enrich their tissue CLA content and thus alter their growth and carcass characteristics.

\section{MATERIAL AND METHODS}

Thirty-six Charollais x Mule ewe lambs (age $10 \mathrm{wks}$; average initial liveweight $29.3 \mathrm{~kg}$ ) were fed three levels of rumen protected CLA (CLA), containing similar levels of the two major CLA isomers (cis-9, trans-11 and trans-10, cis-12), or Megalac (MEG; Volac Ltd., UK) which was fed to control for energy content at each CLA level. The CLA was protected by a lipid based coating which, using the dual-phase marker technique of Faichney (1975) in sheep fitted with rumen and duodenal cannulae, was shown to allow $65 \%$ of the CLA to reach the duodenum. Megalac is a commercially available rumen protected fat ingredient composed of a combination of natural plant oil (palm fatty acids) and calcium. Animals were randomly allocated to one of 7 treatment groups which were fed to achieve a growth rate of $180 \mathrm{~g} / \mathrm{d}$ : basal diet (control; $\mathrm{n}=6$ ), and then basal diet plus 25 g PCLA/kg diet (CLA1; $\mathrm{n}=5$ ), $50 \mathrm{~g}$ PCLA $/ \mathrm{kg}$ diet (CLA2; $\mathrm{n}=5), 100 \mathrm{~g}$ PCLA $/ \mathrm{kg}$ diet (CLA3; n=5), $21.7 \mathrm{~g}$ MEG/kg diet (MEG1; n=5) $43.3 \mathrm{~g} \mathrm{MEG/kg}$ $\operatorname{diet}(\mathrm{MEG} 2 ; \mathrm{n}=5)$ and $86.6 \mathrm{~g} \mathrm{MEG} / \mathrm{kg} \operatorname{diet}(\mathrm{MEG} 3 ; \mathrm{n}=5)$. The trial was conducted over a 10 -week period. At slaughter, samples of subcutaneous adipose tissue and L. dorsi muscle were taken and frozen at $-40^{\circ} \mathrm{C}$. Various carcass parameters were also measured, as shown in Table 1. Lipid was extracted using a 2:1 chloroform: methanol solution. Prior to GC analysis using a $60 \mathrm{~m}$ BPX70 column, adipose tissue (subcutaneous, omental and perirenal) was methylated by base methylation and muscle samples by combined base-acid methylation. Data was analysed by ANOVA to determine the effects of amount of fat $\times$ type of fat.

\section{RESULTS}

In all adipose tissue depots studied, dietary supplementation resulted an amount of fat $\times$ type of fat interaction $(\mathrm{P}<0.02)$ for CLA content (Table 1$)$. The proportions of both cis-9, trans-11 and trans-10, cis-12 CLA accumulated with increasing with CLA inclusion but were not altered with amount of Megalac fed. Although there was no significant effect on CLA cis-9, trans-11 levels, a similar dose accumulation $(\mathrm{P}<0.001)$ of trans-10, cis-12 CLA content with CLA supplementation was determined in the $L$. dorsi muscle. There was however no evidence of any significant alterations in carcass fat or protein levels with dietary CLA supplementation. 
Table 1. Carcass characteristics and conjugated linoleic acid content of sheep tissues

\begin{tabular}{|c|c|c|c|c|c|c|c|c|c|c|}
\hline & & \multicolumn{7}{|c|}{$\operatorname{Diet}^{1}$} & \multirow{2}{*}{ SED } & \multirow{2}{*}{$\mathrm{P}^{\mathrm{a}}$} \\
\hline & & Cont & CLA1 & CLA2 & CLA3 & Meg1 & Meg2 & Meg3 & & \\
\hline \multicolumn{11}{|c|}{ Carcass characteristics } \\
\hline \multirow{3}{*}{\multicolumn{3}{|c|}{$\begin{array}{lr}\text { weight, } \mathrm{kg} & 20.2 \\
\text { fat, g/100 g DM } & 54.8 \\
\text { protein, g/100 g DM } & 34.9\end{array}$}} & 20.3 & 20.5 & 20.8 & 20.6 & 19.7 & 19.7 & 0.77 & 0.437 \\
\hline & & & 57.3 & 57.1 & 55.9 & 57.3 & 58.6 & 55.8 & 2.23 & 0.856 \\
\hline & & & 32.6 & 32.7 & 33.9 & 32.7 & 31.6 & 34.5 & 1.65 & 0.746 \\
\hline \multicolumn{2}{|c|}{ omental wt, g } & 643 & 646 & 663 & 706 & 663 & 663 & 594 & 125.5 & 0.737 \\
\hline \multicolumn{2}{|c|}{ perirenal wt, $g$} & 473 & 491 & 565 & 523 & 534 & 556 & 488 & 97.7 & 0.852 \\
\hline \multicolumn{11}{|c|}{ Conjugated linoleic acid content $t^{b}$ moles/100 moles fatty acid methyl ester } \\
\hline \multirow[t]{4}{*}{ c-9,t-11 } & Sub & 0.89 & 1.09 & 1.34 & 1.95 & 0.78 & 0.92 & 0.83 & 0.206 & 0.020 \\
\hline & Om & 0.67 & 0.95 & 1.23 & 1.77 & 0.71 & 0.80 & 0.73 & 0.134 & $<0.001$ \\
\hline & Peri & 0.45 & 0.68 & 1.00 & 1.62 & 0.46 & 0.49 & 0.51 & 0.101 & $<0.001$ \\
\hline & LD & 1.01 & 1.15 & 1.30 & 1.30 & 0.92 & 1.13 & 0.99 & 0.145 & 0.159 \\
\hline \multirow[t]{4}{*}{$\mathrm{t}-10, \mathrm{c}-12$} & Sub & 0.04 & 0.18 & 0.38 & 0.76 & 0.02 & 0.10 & 0.08 & 0.045 & $<0.001$ \\
\hline & $\mathrm{Om}$ & 0.05 & 0.19 & 0.36 & 0.75 & 0.07 & 0.08 & 0.10 & 0.046 & $<0.001$ \\
\hline & Peri & 0.04 & 0.21 & 0.38 & 0.76 & 0.06 & 0.12 & 0.23 & 0.063 & 0.001 \\
\hline & LD & 0.01 & 0.05 & 0.14 & 0.36 & 0.02 & 0.03 & 0.06 & 0.033 & $<0.001$ \\
\hline
\end{tabular}

${ }^{1}$ basal diet (Cont; $\left.n=6\right)$, and then basal diet plus $25 \mathrm{~g} \mathrm{CLA} / \mathrm{kg} \operatorname{diet}(\mathrm{CLA} 1 ; \mathrm{n}=5), 50 \mathrm{~g} \mathrm{CLA} / \mathrm{kg}$ diet (CLA2; $\mathrm{n}=5$ ), $100 \mathrm{~g} \mathrm{CLA} / \mathrm{kg} \operatorname{diet}(\mathrm{CLA} 3 ; \mathrm{n}=5), 21.7 \mathrm{~g}$ MEG/kg diet (MEG1; $=5$ ) $43.3 \mathrm{~g}$ MEG/ $\mathrm{kg} \operatorname{diet}(\mathrm{MEG} 2 ; \mathrm{n}=5)$ and $86.6 \mathrm{~g} \mathrm{MEG} / \mathrm{kg} \operatorname{diet}(\mathrm{MEG} 3 ; \mathrm{n}=5)$

a $\mathrm{P}$-value and SED for the amount of fat $\times$ type of fat interaction

${ }^{b}$ CLA cis-9, trans-11 (c-9,t-11) and trans-10, cis-12 (t-10, c-12) measured in subcutaneous (sub), omental (om) and perirenal (peri) adipose tissue and $L$. dorsi muscle (LD) samples

\section{DISCUSSION}

The increasing proportions of both cis-9, trans-11 and trans-10, cis-12 CLA in the lambs fed rumen-protected CLA indicates that CLA was incorporated into the tissues. However, there were no significant effects of feeding the protected CLA supplement on any of the carcass parameters measured. This was surprising since several studies have demonstrated that feeding animals CLA at similar levels promotes a decrease in fat content. In the present study, CLA was fed on a body weight basis and, even taking into account the level of rumen protection, the levels were greater than those used by Ostrowska et al. $(1999,2003)$ and so an effect of CLA was expected. Figure 1 indicates that the lambs in this study actually had more trans-10, cis-12 CLA in their subcutaneous adipose tissue than Ostrowska et al. (2003) reported in their pig study in which a repartitioning effect of CLA on carcass composition was seen. 


\section{CONCLUSIONS}

Unlike observations in other species, CLA supplementation did not reduce fat deposition in these sheep. The reasons for this are unknown.

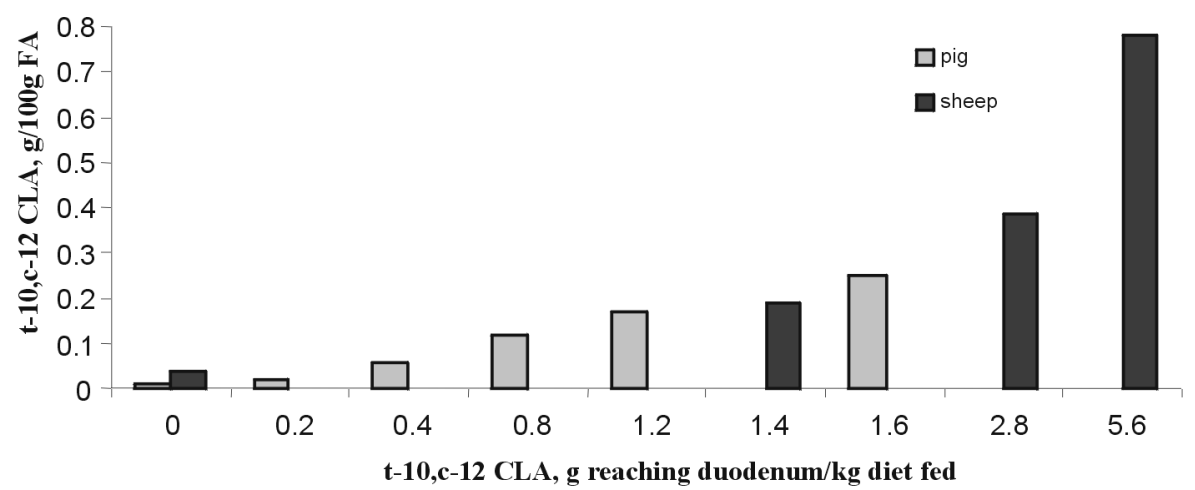

Figure 1. Accumulation of trans-10, cis-12 conjugated linoleic acid in subcutaneous adipose tissue of sheep in this study and pigs (Ostrowska et al., 2003) fed diets supplemented with CLA. The grams of $t-10, c-12$ CLA reaching the duodenum per $\mathrm{kg}$ diet takes into account the relative content of CLA isomers in the diets fed and the sheep data takes into account estimated rumen protection

\section{REFERENCES}

Baumgard L.H., Sangster J.K., Bauman D.E., 2001. Milk fat synthesis in dairy cows is progressively reduced by increasing supplemental amounts of trans-10, cis-12 conjugated linoleic acid (CLA). J. Nutr. 131, 1764-1769

Belury M.A., 1995. Conjugated diemoic linoleate: A polyunsaturated fatty acid with unique chemoprotective properties. Nutr. Rev. 53, 83-89

Dugan M.E.R., Aalhus J.L., Schaefer A.L., Kramer J.K.G., 1997. The effect of conjugated linoleic acid on fat to lean repartitioning and feed conversion in pigs. Can. J. Anim. Sci. 77, 723-725

Faichney G.J., 1975. The use of markers to partition digestion within the gastro-intestinal tract of ruminants In: I. MacDonald, A.C.I. Warner (Editors). Digestion and Metabolism in the Ruminant. Armidale, University of New England, pp. 277-291

Park Y., Albright K.J., Liu W., Storkson J.M., Cook M.E., Pariza M.W., 1997. Effect of conjugated linoleic acid on body composition in mice. Lipids 32, 853-858

Park Y., Storkson J.M., Albright K.J., Liu W., Pariza M.W., 1999. Evidence that the trans-10, cis-12 isomer of conjugated linoleic acid induces body composition changes in mice. Lipids 34, 235-241

Ostrowska E., Muralitharan M., Cross R.F., Bauman D.E., Dunshea F.R., 1999. Dietary conjugated linoleic acids increase lean tissue and decrease fat deposition in growing pigs. J. Nutr. 129, 2037-2042

Ostrowska E., Cross R.F., Muralitharan M., Bauman D.E., Dunshea F.R., 2003. Dietary conjugated linoleic acid differentially alters fatty acid composition and increases conjugated linoleic acid content in porcine adipose tissue. Brit. J. Nutr. 90, 915-928

Sisk M.B., Hausman D.B., Martin R.J., Azain M.J., 2001. Dietary conjugated linoleic acid reduces adiposity in lean but not obese Zucker rats. J. Nutr. 131, 1668-1674

West D.B., Delany J.P., Camet P.M., Blohm F., Truett A.A., Scimeca J., 1998. Effects of conjugated linoleic acid on body fat and energy metabolism in the mouse. Amer. J. Physiol. 275, R667-R672 